\title{
EGFR NP_005219.2:p.N771_P772insH
}

National Cancer Institute

\section{Source}

National Cancer Institute. EGFR NP 005219.2:p.N771 P772insH. NCI Thesaurus. Code C98671.

An insertion of the amino acid histidine between the asparagine at position 771 and the proline at position 772 of the epidermal growth factor receptor protein. 